Marquette University

e-Publications@Marquette

College of Nursing Faculty Research and

Publications

Nursing, College of

$7-1-2010$

Listening Sessions With Latinas: Documenting Life Contexts and Creating Connections

Ruth Belknap

Marquette University, ruth.belknap@marquette.edu

Leona VandeVusse

Marquette University, leona.vandevusse@marquette.edu

Accepted version. Public Health Nursing, Vol. 27, No. 4 (July/August 2010): 337-346. DOI. (C) 2010 Wiley. Used with permission.

This is the peer reviewed version of the following article: "Listening Sessions With Latinas:

Documenting Life Contexts and Creating Connections," which has been published in final form at DOI. This article may be used for non-commercial purposes in accordance With Wiley Terms and Conditions for self-archiving. 


\title{
Listening Sessions With Latinas: Documenting Life Contexts and Creating Connections
}

\author{
Ruth Ann Belknap \\ Assistant Professor, Marquette University College of Nursing \\ Milwaukee, Wisconsin \\ Leona VandeVusse \\ Associate Professor, Marquette University College of Nursing \\ Milwaukee, Wisconsin
}

\begin{abstract}
:
Latinas in the U. S. face significant disparities. Recent immigrants are particularly marginalized due to cultural, immigration, and language barriers. The purpose of this community based participatory research study was to use listening sessions with groups of women to develop a contextual understanding of the lives of Latina immigrants and ultimately better serve the community's needs for domestic violence services.
\end{abstract}

Seven listening group sessions were facilitated and recorded in Spanish, with 63 women participating. The participants also completed a demographic questionnaire. Themes derived from aggregated data from the listening sessions included women's unmet needs, responsibilities, goals, achievements, help-seeking, and intimate partner violence (IPV).

Findings indicated that Latinas' comments were often family-focused and they have many unmet needs. Familiarity with community resources to

Public Health Nursing, Vol. 27, No. 4 (July/August 2010): pg. 337-346. DOI. This article is C Wiley and permission has been granted for this version to appear in e-Publications@Marquette. Wiley does not grant permission for this article to be further copied/distributed or hosted elsewhere without the express permission from Wiley. 
meet needs was not consistent across groups, for example, women who had not utilized domestic violence services were unlikely to know where to obtain help for IPV problems. The ease with which women shared knowledge of resources and offered emotional support to each other during listening sessions supports their use by bilingual public health nurses in communities for education and networking among Latinas.

Keywords: community-based nursing, domestic violence, Latinas, listening sessions, context.

\section{Introduction}

This paper presents the findings from a community based participatory research (CBPR) project conducted in a Midwestern city. The project partners included: a College of Nursing, the Latina Resource Center (LRC) that provides domestic violence services locally, and the women of the surrounding Latino community. The LRC provides bilingual bicultural services to Latinas and their families who have experienced intimate partner violence (IPV), offering case management, advocacy, and support group services to women and their children. The lead nurse researcher has years of clinical and research experience in the area of IPV in the lives of Latinas.

CBPR was chosen to facilitate the partnering of the community with the researcher to meet "three interconnected goals: research, action, and education" (Wallerstein \& Duran, 2003, p. 28). Three principles imbedded in the CBPR approach are: (a) "starting where the people are" to ensure that issues addressed are important to the community, (b) focusing on identification of strengths and resources, and (c) maintaining authentic dialogue between the researchers and the participants in the process of asset and issue identification (Minkler \& Hancock, 2003, p. 136). The research agenda is set by the community members, who share in the process. CBPR is openly emancipatory; community members are active participants in the transformation of their lives (Wallerstein \& Duran, 2003).

\section{Objectives}

The objectives of this project were threefold. CBPR was used to: (a) meet the center's needs for assessment data, (b) document the

Public Health Nursing, Vol. 27, No. 4 (July/August 2010): pg. 337-346. DOI. This article is (C) Wiley and permission has been granted for this version to appear in e-Publications@Marquette. Wiley does not grant permission for this article to be further copied/distributed or hosted elsewhere without the express permission from Wiley. 
contexts of women's lives, and (c) evaluate the demand for increased services.

\section{Background}

As a group, Hispanic women are twice as likely to live in poverty as non-Hispanic women ( $20 \%$ to $11 \%$ respectively) (Gonzales, 2008 ). Hispanic women earn less than non-Hispanics (with a median wage of $\$ 460$ per week compared to $\$ 615)$; immigrant women average even less weekly (\$400). Hispanic women, particularly immigrants, are also less educated than non-Hispanic women and 73\% reported that they do not speak English well (Gonzales). These factors complicate their living situations in the U.S. and impact their health and family stability.

In the Midwestern city in which the study was conducted, $21.6 \%$ of the families live below the national poverty level; the median household income (in 2006 inflation adjusted dollars) was \$33,990, well below the national figure of $\$ 48,451$ (U.S. Census, 2006). The Hispanic population was estimated to be about $15 \%$ of the population (U.S. Census, 2006) and it has continued to grow. Nearly two-thirds are of Mexican descent.

IPV is an important health concern of the Latino population in the U.S. In one study, 34\% of Latinas surveyed had experienced IPV in their country of origin, the U.S., or both (Family Violence Prevention Fund, n.d.). In another descriptive study, nearly half (48\%) of the Latina immigrant participants reported an increase in partner violence after migration to the U.S. (Dutton, Orloff, \& Hass, 2000). Barriers to help-seeking for IPV identified in the Latina immigrant population are high, including language, isolation, immigration-induced economic changes, and legal status. In addition, using home countries as frames of reference may complicate help-seeking because violence against women often does not carry the same consequences as in the U.S. (Bauer, Rodriguez, Quiroga, \& Flores-Ortiz, 2000; Menjivar \& Salcido, 2002).

Knowledge about social factors associated with IPV in Latino immigrants is limited. Quantitative studies have provided some insights. Social support has been identified as a factor in reducing IPV, while greater acculturation is considered a contributing factor to

Public Health Nursing, Vol. 27, No. 4 (July/August 2010): pg. 337-346. DOI. This article is @ Wiley and permission has been granted for this version to appear in e-Publications@Marquette. Wiley does not grant permission for this article to be further copied/distributed or hosted elsewhere without the express permission from Wiley. 
increased rates of IPV (Firestone, Lambert and Vega, 1999). Denham et al. (2007) found that Latinas who experienced IPV (with an average time in the U.S. of 6.34 years) were more than twice as likely to lack social support as either Latinas who did not experience IPV or nonLatina survivors of IPV. In a case control study with 182 cases and 147 controls, researchers (Lipsky, Caetano, Field, \& Larkin, 2006) examined the relationship between IPV and utilization of health and social services. They found that low acculturation in Latinas was associated with less use of services, including any type of healthcare, particularly among abused women.

Development of contextual understanding is often addressed in qualitative studies. Adams and Campbell (2005) conducted 10 semistructured interviews to develop an understanding of Mexican immigrant women's conceptualization of abuse. The women readily identified poor relationships and IPV as problems in their community. They cited socio-cultural pressures, such as male domination and men's inability to cope with immigration changes, as contributing factors. In a focus group study (Klevens et al. 2007), IPV was described as highly prevalent by all 77 participants. Women in this study estimated that IPV occurred daily in the lives of 5 out of 10 families. These women also discussed serious community problems, including "discrimination, language barriers, drug and alcohol use, teenage pregnancy, gangs and child abuse" (p. 145). Additionally, they indicated a belief that neighbors should not get involved in matters of IPV and generally were not helpful to victims. Other women in a grounded theory study stated that there was a lack of awareness in their community that IPV was inappropriate (Crandall et al., 2005). They further identified that women were reluctant to share their experiences of abuse due to embarrassment and shame.

Together, the results of these qualitative and quantitative studies illuminate the complexity of contextual factors that influence understanding of and response to IPV in the lives of Latina immigrants. This study used listening group sessions during which Latinas were asked to describe their lives in response to discussion prompts to provide a picture of their life contexts.

Public Health Nursing, Vol. 27, No. 4 (July/August 2010): pg. 337-346. DOI. This article is (C Wiley and permission has been granted for this version to appear in e-Publications@Marquette. Wiley does not grant permission for this article to be further copied/distributed or hosted elsewhere without the express permission from Wiley. 
NOT THE PUBLISHED VERSION; this is the author's final, peer-reviewed manuscript. The published version may be accessed by following the link in the citation at the bottom of the page.

\section{Research Questions}

There were 4 research questions in this study. They were: (a) what do Latinas in listening sessions report as contextual factors in their lives, (b) when IPV spontaneously arises in a group setting, what do women say, (c) what is the frequency of IPV among women in the sessions either personally or by knowing someone who has experienced IPV, and (d) how familiar are women with resources for IPV survivors?

\section{Methods}

\section{Design}

This study was exploratory and descriptive. The design mixed qualitative listening sessions that were similar to focus groups, with quantitative methods consisting of data from a short demographic questionnaire and tallies of thematic comments made during the listening group discussions. The decisions about data collection began with a discussion between the nurse researcher and the LRC program director. The director was familiar with a community engagement model used in St. Paul, Minnesota, for a similar project. This model was adapted to the purposes of this study. Consent was obtained from Casa de Esperanza (2005) to use their publication, Fuerza Unida: A Manual for Engaging Communities, as the organizing framework for this study. The format for listening sessions and the brief demographic questionnaire were adapted from this manual. The questions used as discussion prompts for the listening sessions are listed in Table 1.

\section{Sample}

A total of seven different listening groups were held at a variety of community locations, shown in Table 2. Only one group was convened expressly for this study. The other six sessions were conducted with existing groups during their regularly scheduled meeting times.

A total of 63 women participated, ranging from 5-16 women per group as shown in Table 2, with an average of 9 per session. Spanish was the first language of all participants. The majority, $51(81 \%)$ of

Public Health Nursing, Vol. 27, No. 4 (July/August 2010): pg. 337-346. DOI. This article is @ Wiley and permission has been granted for this version to appear in e-Publications@Marquette. Wiley does not grant permission for this article to be further copied/distributed or hosted elsewhere without the express permission from Wiley. 
the women, were from Mexico, 7 (11\%) from Puerto Rico, 1 (2\%) from the U.S., with $4(6 \%)$ not stated. The average number of years that participants had been in the city ranged from less than 1 to 34.5, with an average of 7.9.

Participants' ages were reported in 10-year increments, with the exception of the initial category, which was shorter (18-21 years). Age ranges for the groups are shown in Table 2 . Most women in the seven groups reported they were $31-40$ years old, which was calculated as the participants' median age range. Employment outside the home was reported by 21 (33\%) of the participants. Their mean hourly wage was $\$ 8.43$, although $6(27 \%)$ did not provide salary information.

Marital status of the participants was reported as follows: 21 (33\%) were currently married, 17 (27\%) divorced or separated, 14 (22\%) living with a partner, while 10 (16\%) were single, with 1 (2\%) missing data. Nearly all participants were mothers; 59 of the 63 (94\%) participants reported a total of 145 children, with an average of 2.5 per participant. The children ranged in age from infancy to17 years, with a mean age of 6 years old, although ages were not identified for $29(20 \%)$ of the reported children. Although the number of adults living in their homes ranged from 1 to 9 , the latter was an outlier. By also using the mode (2) and median (2.64), an average of 2.5 adults living in their homes was calculated.

\section{Measures}

Quantitative data were obtained through a brief questionnaire. This instrument included the following information: community agencies where the woman had sought help, whether or not she or someone she knew had been mistreated by a partner, where to seek help for IPV, as well as basic demographic information.

Qualitative data were collected through listening sessions. Sessions were conducted in Spanish by bilingual bicultural volunteers who were trained and supported by the lead researcher and her research assistant, who was also bilingual and bicultural. The volunteers participated in a day-long workshop that included didactic sessions and practice in facilitating mock listening sessions. Each volunteer was trained to fill two roles, discussion facilitator and recorder. All groups were conducted in Spanish, the preferred

Public Health Nursing, Vol. 27, No. 4 (July/August 2010): pg. 337-346. DOI. This article is @ Wiley and permission has been granted for this version to appear in e-Publications@Marquette. Wiley does not grant permission for this article to be further copied/distributed or hosted elsewhere without the express permission from Wiley. 
language of the participants, some of whom were monolingual Spanish speakers. One of the bilingual bicultural trained volunteers, in addition to the researcher and/or research assistant, was present at each group listening session.

At the start of each session, informed consent, following university IRB regulations, was obtained from each participant and the brief questionnaire completed. Women in each group were then asked by the trained volunteer facilitator to respond to the discussion prompts that were designed to elicit information about their daily lives, personal achievements, goals for the future, needs, and help-seeking. (See Table 1.) The intent was to encourage women to talk about all aspects of their lives to elicit a rich contextual description. Notes were taken in Spanish during the session by the trained volunteer recorder on flip chart that all could easily view. The sessions were also taperecorded with the participants' permission. Women received a small gift bag for participating that included information about community resources.

\section{Analytic Strategy}

Data from the listening sessions consisted of the women's comments in response to the discussion prompts (Table 1 ). This included transcriptions of audio recordings and the information handrecorded during the group listening sessions on flip charts. Analysis by the lead researcher and research assistant began with reading the transcripts and flip charts in Spanish, then translating all the data to English before coding to facilitate discussion of the meanings of words and ideas that were not easily translated, until they reached agreement.

Using women's comments as the unit of analysis, participant data on the flipcharts were content analyzed with a classic approach (Krippendorff, 1980). Transcriptions from each listening session were analyzed concurrently with the flip chart data to verify common content areas and identify unique outlier statements; then summary impressions were written for each listening session. Next, similar content areas from the data sources were synthesized into themes that explained the participants' comments. Frequencies of the women's comments that related to each theme were calculated. Patterns were then sought among the themes according to the women's emphases;

Public Health Nursing, Vol. 27, No. 4 (July/August 2010): pg. 337-346. DOI. This article is @ Wiley and permission has been granted for this version to appear in e-Publications@Marquette. Wiley does not grant permission for this article to be further copied/distributed or hosted elsewhere without the express permission from Wiley. 
these thematic patterns were aggregated into categories that could be represented as percentages of comments within each theme. The categories in each theme totaled $100 \%$. Data from all seven sessions were aggregated, rather than examining information shared by individual women. Consolidating the information was possible because of the significant commonalities among participant characteristics and content across the groups; no one group presented as a distinctive outlier in their comments. Together, the data from the seven listening groups formed a picture of the life contexts of the Latina participants in this community.

\section{Results}

The major findings of this study are reported as themes; subfindings within the themes are called categories. The six themes of this study were: (a) unmet needs, (b) responsibilities, (c) goals, (d) achievements, (e) help-seeking, and (f) IPV. All six themes had varying numbers of comments coded. The first 4 themes had common categories across them that represented emphases made by the participants. In descending order, the highest number of women's comments occurred in Theme 1, Unmet Needs, with a total of 185 comments. The number of responses in Themes 2-4 are as follows: Responsibilities $(n=83)$, Goals $(n=74)$, and Achievements $(n=58)$. The comparable emphases reported by the women that were readily categorized across Themes 1-4 are shown in Figure 1: (a) family and household related, (b) self, (c) work outside the home, and (d) investing in non-family members. The variations in emphases in the women's comments coded in each category are shown as percentages across the first four themes in Figure 1 . The category of family and household related comments was most frequently expressed in these themes. In addition to frequencies and categories, illustrative examples of the women's comments are reported for each theme. The fifth and sixth themes, Help-Seeking and IPV, did not have categories in common with the other 4 themes. For example, the sixth theme, IPV, was not a discussion prompt, but did appear on the demographic questionnaire and spontaneously occurred as an important topic during several listening groups. Therefore, these data are reported exclusively in the text and explained more fully with substantiating quotations from the transcripts.

Public Health Nursing, Vol. 27, No. 4 (July/August 2010): pg. 337-346. DOI. This article is (C) Wiley and permission has been granted for this version to appear in e-Publications@Marquette. Wiley does not grant permission for this article to be further copied/distributed or hosted elsewhere without the express permission from Wiley. 
NOT THE PUBLISHED VERSION; this is the author's final, peer-reviewed manuscript. The published version may be accessed by following the link in the citation at the bottom of the page.

\section{Theme 1: Unmet Needs}

In Figure 1, the percent of women's comments that were coded for the theme, unmet needs, were reported as categories; family and household-related issues predominated. Many of the participants' comments were quite general, "I need money for bills, rent, children". There were also specific statements of their own needs for immigration assistance, education, learning to speak and read English. Complex responses were also expressed for example, "Finding a stable job, economic problems, and I am afraid that my husband will send immigration after me after he finds out that I submitted an application for him to pay child support." Overall, women commented that good paying employment would help to meet their needs.

\section{Theme 2: Responsibilities}

Women described household work as consuming most of their time, as shown in Figure 1. This usually involved caring for their own children and grandchildren or working as child care providers for others. Additional work at home was described as food preparation, housecleaning, and laundry. Women described long days; many women, whether working in and/or outside the home, said they woke before 6 a.m. to begin. One woman with four children stated, "I'm a house wife. I work hard; I rest a little. I work packing hamburgers; it's cold". Work away from home comprised the rest of women's reported responsibilities and ranged from packing hamburgers (described as cold and difficult) to owning a business (described as a source of fulfillment).

\section{Theme 3: Goals.}

The women most frequently reported their goals as wellbeing and security for their families, often expressed as desires that their children be educated and successful. The second most frequently coded category in this theme was self focused goals, such as getting an education and becoming a U.S. citizen. Women expressed a desire to gain the skills and preparation necessary for meaningful employment. Specific careers of interest included teacher, labor and delivery nurse, hospital interpreter, lawyer, and restaurant owner. In a small percent of the comments, women spoke of goals in which they planned to invest their caring beyond their own families, such as

Public Health Nursing, Vol. 27, No. 4 (July/August 2010): pg. 337-346. DOI. This article is (c) Wiley and permission has been granted for this version to appear in e-Publications@Marquette. Wiley does not grant permission for this article to be further copied/distributed or hosted elsewhere without the express permission from Wiley. 
reuniting other families that had become estranged, adopting several children, and providing housing to those in need.

\section{Theme 4: Achievements.}

Theme 4 had a lower number of women's comments coded than the previous themes. However, pride in personal achievements was most commonly reported related to their families and householdrelated events. Specific details on family-related achievements are exemplified in these two brief quotations: "My children graduated from here; the money I earned paid their tuition" and "Helping my husband to not use drugs". Another frequently coded category in the theme of achievements focused on the women themselves, such as learning English, earning a degree from the university, becoming a U.S. citizen, or obtaining a driver's license or a permit to work. Several women cited raising their self-esteems as their personal achievement. One explained the importance of this by saying, "my self-esteem, because everything else comes from that." Others spoke of being independent as sources of their pride, as noted in the two following statements: "not needing a man" and "living alone for one year, getting my divorce, getting a job and being able to work to get my children back [from foster care]". Proportionately more women commented on 'work outside the home' as one of their future goals than among their current achievements (Figure 1). Similarly, none indicated that the goal of caring for others out side their family had been achieved to date.

\section{Theme 5: Help-Seeking}

The categories in Theme 5, Help-Seeking, were not comparable to those found in the first four themes or the sixth. When commenting on help-seeking, over one-half of the total comments coded in this theme $(n=171)$ were general, with the women indicating they would "ask for help", but not specifying to whom they would turn. Over onefourth of the remaining women's comments in Theme 4 identified seeking help and resources for problems from specific community agencies, often identifying direct support from the pre-existing groups to which they belonged. Other types of assistance were mentioned infrequently, cumulatively accounting for less than one-sixth of the help-seeking comments; these included relying on various family

Public Health Nursing, Vol. 27, No. 4 (July/August 2010): pg. 337-346. DOI. This article is @ Wiley and permission has been granted for this version to appear in e-Publications@Marquette. Wiley does not grant permission for this article to be further copied/distributed or hosted elsewhere without the express permission from Wiley. 
members, the legal system, health care providers, and most rarely, the church.

Women debated the value of some of the help-seeking suggestions. For example, when a woman stated "clinics" could be helpful, the discussion shifted to difficulties with long waits, communication problems, and lack of access to care. As noted by one woman, "Honestly, we are undocumented, and they almost always reject us wherever we go." Another stated,

What happens is that in my case I don't understand English. I don't have the courage to ask for a translator, and besides they take a very long time, so then we don't receive good service that we require. The majority of us have that problem. There are people who can help us but we don't understand the language or there isn't anyone that can translate for us, or they [translators] don't arrive quickly enough. You start to become anxious and we would rather leave.

The women in the IPV support groups often indicated that prior to joining the group they did not have anyone to help with their problems. One stated, "I don't have family here and I don't turn to my husband for help. Now I go to [advocate at agency]". Another reported, "I would not go to anyone for help, but now I come here." Women in pre-existing groups knew a particular set of social service agencies that had resources related to the group's purpose. However, specific community resources were not uniformly identified across the groups.

\section{Theme 6: IPV}

Specific questions or prompts about relationships were not included in the listening session guide. However, to capture data specific to IPV and related community resources, the brief demographic questionnaire completed by each woman contained two questions about IPV (as noted in Table 1). The inclusion of the question about mistreatment on the brief questionnaire was intended to provide both baseline data as well as a cue that abuse was a topic that could be discussed during the session.

The demographic questions were tabulated after the sessions, so the extent of IPV in the sample was not known to the facilitators

Public Health Nursing, Vol. 27, No. 4 (July/August 2010): pg. 337-346. DOI. This article is @ Wiley and permission has been granted for this version to appear in e-Publications@Marquette. Wiley does not grant permission for this article to be further copied/distributed or hosted elsewhere without the express permission from Wiley. 
during the listening groups. Of the 63 women who participated in the listening session groups, $38 \%$ indicated on the questionnaire that they had either been mistreated or knew a woman who had been mistreated, $41 \%$ answered "no" to this question, and $21 \%$ gave no response.

In three of the seven listening sessions, the one-time group, an abuse support group, and a mothers' group, women spontaneously raised issues of family violence. Serious issues of violence were discussed in the group that was convened one-time for the purpose of the listening session. One of the women in this group described what happened when she told her husband (in Mexico) she was going to leave him:

He said, "Well then I'm going to kill you." He always has a gun under his pillow. He put the gun to my head; it was 7 in the morning so I was still in bed. I put my hand up and the gun went off towards the ceiling. He tried to choke me and my oldest daughter threw herself on him and he threw her off. Then he hit me on the head. I thought he had hit me with the gun, I thought my head would explode. He hit me again on the head and it was like I was seeing stars and birds flying around. I think my daughter threw herself on him and said "if you want to kill her kill me instead". And he said, "OK, then I'll kill you too." (Crying) He took a punch at her and I put my hand in between them and his hand slid.

The women in the group listened in a matter-of-fact manner while she was encouraged to tell her whole story. As she spoke, the women offered support.

Women in one of the two ongoing abuse support groups spoke openly about men controlling women's activities and money. Several of the women spontaneously identified serious problems with husbands or partners that complicated their financial situations, for example,

When I work I have to give him [husband] my paycheck. He manages the money. He doesn't let me go out to any place. I can only come to group. The only money I earn is by being a baby sitter; my husband doesn't give me any money. He... pays the rent and the bills so he says, "Why do you need money?"

Public Health Nursing, Vol. 27, No. 4 (July/August 2010): pg. 337-346. DOI. This article is (c) Wiley and permission has been granted for this version to appear in e-Publications@Marquette. Wiley does not grant permission for this article to be further copied/distributed or hosted elsewhere without the express permission from Wiley. 
Even if he had money he wouldn't give it to me...because he drinks a lot.

These women also knew where to go to help with these issues. In contrast, a participant in one of the mothers' group stated,

A lot of them [women] don't want to say but ... physical abuse....the problem there is no one to go to....I don't say it for myself but more for my friends that I have who get hit; it is always because of what people will say that they keep silence. One of them got burnt badly and she didn't say anything because she didn't know who to go to.

Although the women nodded in agreement while this participant was speaking, women in the mothers' groups were generally not open about discussing IPV. They indicated women are primarily silent on this issue and that they themselves were not familiar with resources in the community for women who have experienced IPV.

\section{Discussion}

\section{Summary}

The primary commonality across the groups was women's dedication to home and family. Their focus on home and family were consistent with what one would expect to see in a Latina population (Falicov, 1998). Most of the unmet needs the women identified supported the centrality of their families and households in their lives. There was a diversity of family functioning patterns represented in the women's responses. Women who described poorly functioning families wanted to improve the situation. Those who described healthy families expressed a desire to maintain family functioning and articulated plans for advancement for themselves and various family members through education and careers. When data about goals and achievements were examined, home and family remained central, but foci beyond them also emerged. Women described goals of individual self development, such as increasing their education by learning English and/or driving.

The participants demonstrated a range of understanding of community resources. Women who regularly attended a group, regardless of its purpose, expressed greater familiarity with community resources. Members of ongoing groups were aware of

Public Health Nursing, Vol. 27, No. 4 (July/August 2010): pg. 337-346. DOI. This article is (c) Wiley and permission has been granted for this version to appear in e-Publications@Marquette. Wiley does not grant permission for this article to be further copied/distributed or hosted elsewhere without the express permission from Wiley. 
differing sources of community support, but with little overlap across groups. It is possible that women in preexisting groups are less isolated, but they may continue to function within circumscribed areas of the broader community.

Women who were members of ongoing groups with foci other than IPV were less open about the issue and less likely to know about formal support resources than women who belonged to IPV groups. Women who were not members of an existing group, when put into a group setting, readily shared their difficulties, including IPV. The women in the group convened for the study had a considerable store of constrained emotions and troubles they were willing to discuss. They were not able to articulate ways in which they might change their circumstances or identify specific sources of community support.

\section{Limitations}

This study was limited by aggregating data from women from different Spanish-speaking cultures. Although the sample was primarily Mexican, it is possible that immigrant women from other countries may have differing perspectives. The study included participants from primarily ongoing, established groups; this could affect their comfort levels and possible pre-existing biases. Additionally, follow-up with women after the analysis could have strengthened the study.

\section{Recommendations}

Future work could include data from more listening groups conducted in Spanish. Comparison of data from women in specific immigrant groups could be enlightening. Also, comparing pre-existing groups' data to that from newly-formed groups, or convening only women who do not yet know each other, could expand the understanding of Latinas and their contexts.

\section{Nursing Implications}

Listening sessions provided detailed information about the context of the Latina participants' lives needed in planning services. Given the general ease with which women shared problems and resources, PHNs could use listening sessions productively with community women, either by connecting them to existing groups or

Public Health Nursing, Vol. 27, No. 4 (July/August 2010): pg. 337-346. DOI. This article is (c) Wiley and permission has been granted for this version to appear in e-Publications@Marquette. Wiley does not grant permission for this article to be further copied/distributed or hosted elsewhere without the express permission from Wiley. 
forming new ones. Listening sessions convened by PHN'S can serve as a safe place for emotional unburdening where mutual supports are developed. Social support has been found to reduce IPV in the Latina population (Firestone et al. 1999) and has been identified as a protective factor in IPV prevention (Lown \& Vega 2001). In this study, participants in all the listening sessions spontaneously offered support to each other when descriptions of problems arose, even in the group convened specifically for this study. This suggests groups might easily be formed among immigrant women and provide a potential source of support for previously isolated women. Forming listening sessions is a nursing intervention that could be used to reach recent immigrant women, build social support, and enhance knowledge and utilization of community resources.

Formation of ongoing sessions could be accomplished by PHNs partnering with community agencies and training community women as facilitators. Bringing together women who are otherwise unlikely to interact can be an effective way for women to share their knowledge and experiences about existing community resources. In this way, primary, secondary, and tertiary women's health needs can be addressed on an aggregate level. This project demonstrated that a college of nursing and a community agency can partner to assess and subsequently plan program enhancements.

\section{References}

Adams, S. B., \& Campbell, R. (2005). Immigrant Latinas' conceptualizations of intimate partner violence. Violence Against Women, 11(10), 13411364.

Bauer, H. M., Rodriguez, M. A., Quiroga, S. S., \& Flores-Ortiz, Y. G. (2000). Barriers to health care for abused Latina and Asian immigrant women. Journal of Health Care for the Poor \& Underserved, 11(1), 33-44.

Casa de Esperanza. (2005). Fuerza Unida: A manual for engaging communities. Retrieved April 24, 2008, from http://www.casadeesperanza.org/en/manuals.html\#fuerzaunida.

Crandall, M., Senturia, K., Sullivan, M., \& Shiu-Thornton, S. (2005). Latina survivors of domestic violence: Understanding through qualitative analysis. Hispanic Health Care International, 3(3), 179-187.

Public Health Nursing, Vol. 27, No. 4 (July/August 2010): pg. 337-346. DOI. This article is @ Wiley and permission has been granted for this version to appear in e-Publications@Marquette. Wiley does not grant permission for this article to be further copied/distributed or hosted elsewhere without the express permission from Wiley. 
NOT THE PUBLISHED VERSION; this is the author's final, peer-reviewed manuscript. The published version may be accessed by following the link in the citation at the bottom of the page.

Denham, A. C., Frasier, P. Y., Hooten, E. G., Belton, L., Newton, W., Gonzalez, P., et al. (2007). Intimate partner violence among Latinas in eastern North Carolina. Violence Against Women, 13(2), 123-140.

Dutton, M., Orloff, L., \& Hass, G. A. (2000). Characteristics of help-seeking behaviors, resources, and services needs of battered immigrant Latinas: Legal and policy implications. Georgetown Journal on Poverty Law and Policy, 7(2), 245-305.

Falicov, C. J. (1998). Latino families in therapy: A guide to multicultural practice. New York: Guilfford Press.

Family Violence Prevention Fund. (n.d.). Immigrant women programs. Retrieved April 24, 2008, from http://endabuse.org/programs/immigrant

Firestone, J. M., Lambert, L. C., \& Vega, W. A. (1999). Intimate violence among women of Mexican origin: Correlates of abuse. Journal of Gender, Culture, and Health, 4(2), 119-134.

Gonzales, F. (2008) Hispanic women in the United States, 2007. Washington, DC: Pew Hispanic Center.

Klevens, J., Shelley, G., Clavel-Arcas, C., Barney, D. D., Tobar, C., Duran, E. S., et al. (2007). Latinos' perspectives and experiences with intimate partner violence. Violence Against Women, 13(2), 141-158.

Krippendorff, K. (1980). Content analysis: An introduction to its methodology. Beverly Hills: Sage.

Lipsky, S., Caetano, R., Field, C. A., \& Larkin, G. L. (2006). The role of intimate partner violence, race, and ethnicity in help-seeking behaviors. Ethnicity \& Health, 11(1), 81- 100.

Lown, E. A., \& Vega, W. A. (2001). Prevalence and predictors of physical partner abuse among Mexican American women. American Journal of Public Health, 91(3), 441-445.

Menjivar, C., \& Salcido, O. (2002). Immigrant women and domestic violence: Common experiences in different countries. Gender and Society, 16(6), 898-920.

Minkler, M., \& Hancock, T. (2003). Community-driven asset identification and issue selection. In M. Minkler \& N. Wallerstein (Eds.), Communitybased participatory research for health (pp. 135-154). San Francisco: Jossey-Bass.

U. S. Census. (2006). 2006 American community survey. Table C03001. Hispanic or Latino origin by specific origin. Retrieved April 28, 2008.

Public Health Nursing, Vol. 27, No. 4 (July/August 2010): pg. 337-346. DOI. This article is @ Wiley and permission has been granted for this version to appear in e-Publications@Marquette. Wiley does not grant permission for this article to be further copied/distributed or hosted elsewhere without the express permission from Wiley. 
NOT THE PUBLISHED VERSION; this is the author's final, peer-reviewed manuscript. The published version may be accessed by following the link in the citation at the bottom of the page.

Wallerstein, N., \& Duran, B. (2003). The conceptual, historical, and practice roots of community-based participatory research and related participatory traditions. In M. Minkler \& N. Wallerstein (Eds.), Community-based participatory research for health (pp. 27-52). San Francisco: Jossey-Bass.

\section{About the Authors}

Ruth Ann Belknap : Marquette University College of Nursing, PO Box 1881, Clark Hall, Milwaukee, WI 53201-1881.

E-mail: ruth.belknap@marquette.edu 
NOT THE PUBLISHED VERSION; this is the author's final, peer-reviewed manuscript. The published version may be accessed by following the link in the citation at the bottom of the page.

TABLE 1. Questions for Listening Sessions and on Demographic Questionnaire

Spanish version used English translation

Discussion prompts used at listening sessions

1. ¿Que haces durante el dia? importantes que enfrentas a diario?

3. Nombre algún éxito personal que represente un orgullo para ti y por qué.

4. Cuándo tienes un problema, ¿A quién acudes?

5. Si fijaras una meta o podrias realizar un sueño o deseo, ¿Cuál sería esa meta y que necesitarías para verla realizada?
1. What do you spend most of your day doing?

2. What are your most important day-today needs?

3. List one personal achievement you are proud of and why.

4. To whom do you turn when you have a problem?

5. If you could set a personal goal, realize a dream or wish, what would that be? What would you need to reach that goal?

Additional questions about IPV that appeared on the demographic questionnaire
1. ¿Usted u otra persona que usted
1. Have you or someone you know been
conoce ha sido maltratada por su
mistreated by a partner, spouse or

Public Health Nursing, Vol. 27, No. 4 (July/August 2010): pg. 337-346. DOI. This article is @ Wiley and permission has been granted for this version to appear in e-Publications@Marquette. Wiley does not grant permission for this article to be further copied/distributed or hosted elsewhere without the express permission from Wiley. 
NOT THE PUBLISHED VERSION; this is the author's final, peer-reviewed manuscript. The published version may be accessed by following the link in the citation at the bottom of the page.

Spanish version used English translation

pareja (esposo/novio)? boyfriend?

2. ¿Si usted u otra persona que usted

2. If you or someone you know had this conoce tuviera este problema a quien problem who would you turn to? recurriría?

Note. Adapted from the Fuerza Unida manual (Casa de Esperanza, 2005) 
NOT THE PUBLISHED VERSION; this is the author's final, peer-reviewed manuscript. The published version may be accessed by following the link in the citation at the bottom of the page.

TABLE 2. Types and Characteristics of Seven Listening Groups

\begin{tabular}{lcccc}
\hline \multicolumn{1}{c}{ Site } & & Purpose of & Number (\%) & Age \\
\multicolumn{1}{c}{ Location } & Pre-existing & Group & of Women & Range in \\
& Group & Convening & $(\mathrm{n}=63)$ & Years \\
\hline Food pantry & No & Listening session & $5(8 \%)$ & $18-30$ \\
Church & Yes & Women's circle & $8(13 \%)$ & $18-50$ \\
Church & Yes & Women's circle & $8(13 \%)$ & $22-60$ \\
Community agency & Yes & Mothers' group & $10(16 \%)$ & $18-50$ \\
Community agency & Yes & Mothers' group & $16(25 \%)$ & $18-40$ \\
Community agency & Yes & Support for abused & $6(10 \%)$ & $22-60$ \\
Community agency & Yes & Support for abused & $10(16 \%)$ & $22-60$ \\
& & & & \\
\hline
\end{tabular}

Public Health Nursing, Vol. 27, No. 4 (July/August 2010): pg. 337-346. DOI. This article is @ Wiley and permission has been granted for this version to appear in e-Publications@Marquette. Wiley does not grant permission for this article to be further copied/distributed or hosted elsewhere without the express permission from Wiley. 
NOT THE PUBLISHED VERSION; this is the author's final, peer-reviewed manuscript. The published version may be accessed by following the link in the citation at the bottom of the page.

Figure 1. Percent of Categorized Comments of 63 Latinas According to Theme

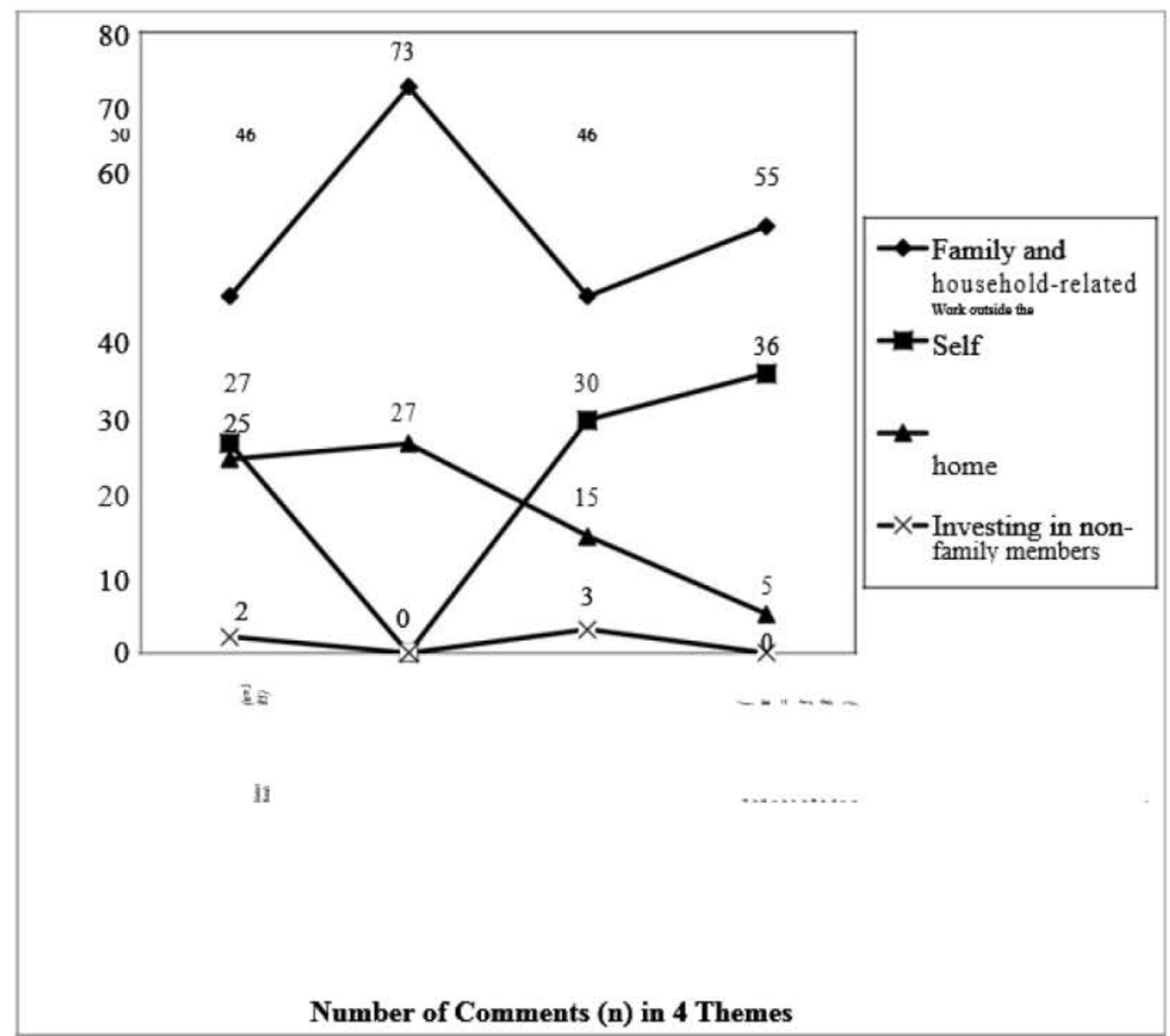

Public Health Nursing, Vol. 27, No. 4 (July/August 2010): pg. 337-346. DOI. This article is @ Wiley and permission has been granted for this version to appear in e-Publications@Marquette. Wiley does not grant permission for this article to be further copied/distributed or hosted elsewhere without the express permission from Wiley. 